\title{
A narrative approach towards identity research within a paradigm of hermeneutic interpretivism
}

\author{
E.A. Kruger \\ Researcher at Department of Music, University of Pretoria \\ Prof. W. Van Wyk \\ Professor in Music at University of Pretoria \\ Dr. H.S. Rhoodie \\ Lecturer at Department of Music at University of Pretoria
}

\begin{abstract}
Research explored musical identity as phenomenon by interpreting the narratives of undergraduate students of Western Art Music at a South African tertiary institution. The participating music students shared what they perceived as reallife experiences and defined their views on human self-definition with reference to their chosen study field. The research approach featured a philosophical framework of hermeneutic interpretivism. Such a non-positivist approach viewed the lived experiences of the music students as existing not on their own, but as being dependent on interpretation to establish the meanings these students attributed to musical identity. The methodology included a qualitative approach which was done from a narrative perspective through analysis of data and interpretation of told life stories. A philosophical framework of hermeneutic interpretivism implies an integration of unfamiliar knowledge or content into existing knowledge, context or content. This interpretation of narratives was done through the application of the hermeneutic circle.
\end{abstract}

Keywords: Hermeneutic interpretivism; narrative; storytelling; identity research; music education;

Identity research has been established as a widely recognised topic within various disciplines (Spychiger, 2017). The recognition of identity as a $20^{\text {th }}$ century phenomenon hascaused a fundamental change in the cultural landscape of the world (Pöder\&Kiilu, 2015). Modern living gives emphasis to individualism and human beings are recognised as single persons who have become increasingly aware of their unique individuality.

This researcher explored available research possibilities in terms of a narrative approach within the academic field of identity research. It was found that academics view the concept of 'narrative' in numerous different ways. The narrative approach that was eventually decided upon by the researcher could possibly serve as a guideline for researchers to conduct narrative research within a hermeneutic interpretivism paradigm.

\section{Identity research}

The question that defines identity research will always be 'Who am I?' The answer to the question will be shaped by a person's activities, contexts and relationships (Talbot, 2013). When a person wants to answer this question about the self, he or she will do so with reference to his or her own understanding of knowledge, relationships, opinions and emotions. Consequently, self-understanding will always be within a specific context of social interaction and daily life (Dys, Schellenberg, \& McLean, 2017; Elliott, 2001).

A complex system of many factors creates the context for identity exploration. At its root, identity development is a cognitive action, because one needs to think about concepts like self-awareness and self-reflection. This thinking about the self will take place within the context of 'lived' experiences, and as such, the development of identity is additionally shaped by socio-cultural circumstances and relationships with other people. Therefore, research on personal identity always includes these comprehensive personal 'lived' experiences when explored by researchers (Clandinin, 2006).

A person's identity or self-concept is defined by his or her orientation towards all aspects of lived experiences (De Fina, 2003). Identity is not a fixed concept, but an on-going process, because of the multiple influences, practices, relationships and experiences within a person's everyday reality (Walshaw, 2008). This developing process of the understanding of one's self implies continuity. It will constantly be influenced by one's own thoughts, likes or dislikes, and will continuously be influenced by changing social interactions and all personal experiences (Evans \& McPherson, 2015; Horowitz, 2012).

\section{Musical identity}


This article is a report of the methodology that was followed on research that was conducted to interpret the narratives of selected undergraduate students of Western Art Music at a South African tertiary institution.

The research set out to describe the experiences and the lives of these music students and the meanings they attribute to their musical identities. Hargreaves, Miell and MacDonald (2002) define the concept of identity in the field of music as being linked to the ways in which musicians see themselves within a cultural context. Musical identity is based on personal, emotional, social and musical competencies. Thus, to define musical identity, one can ask: Who am I through all musical doings? (Gruhn, Täht, Kiilu, Ristmägi, \&Pöder, 2017). However, the point of departure in the identity research of musicians took it for granted that musicians possess a special aptitude.

Green (2011) explains that aspects like individual musical experiences, membership of numerous social groups, personal musical tastes, values, practices, skills and knowledge are all included when musical identity as a phenomenon is explored.Identity research requires as much information as possible about a person and as such the study included an investigation of as many sub-categories of the music students' lived experiences as possible.

\section{Report on narrative design}

\subsection{Introduction}

Creswell (2013) describes narrative research as comprising many forms and analytical methods, and states that the defining feature of such research is collected stories from individuals. Morgan (2000) elaborates, pointing out that these individuals are regarded as the experts of their own lives.

\subsection{Interdisciplinary application of a narrative approach}

Since the 1980s, researchers across many disciplines ${ }^{1}$ have been rediscovering people's natural narrative characteristics (Ely, 2007; Gallagher, 2007; May, 2012; Riessman, 1993; Robert \&Shenhav, 2014; Sandelowski, 1991). Narrative approaches have entered almost every discipline and many narrative studies are cross-disciplinary.

Within the field of human sciences, various narrative approaches are used - by realists, postmodernists and constructionists. There is a disagreement on the origins and precise definitions of terminologies and methodologies, and it is rare to find similar definitions of these terms (Lieblich, Tuval-Mashiach, \&Zilber, 1998; Mitchell \&Egudo, 2003; Riessman\& Speedy, 2007; Robert \&Shenhav, 2014). Polkinghorne (1995) warns that within qualitative research literature, the term 'narrative' is given wide-ranging meanings and is, therefore, used in an equivocal manner. This has led to a lack of clarity associated with the term and to the way in which it is applied.

Different terms that are commonly (even interchangeably) used to refer to narrative approaches are: 'narrative research', 'life history', 'life story', 'storied narratives', 'narratives', 'narrative analysis', and 'narrative inquiry' (Hatch \& Wisniewski, 1995; Clandinin, 2007; Lieblich et al., 1998). However, Polkinghorne (1995) prefers to use 'analysis of narratives' instead of 'narrative analysis'. The former implies studies whose data consists of stories and the latter refers to studies whose data consists of events, happenings or actions, and where the analysis thereof produces stories, such as case studies, histories or biographies. Furthermore, Polkinghorne (1995) sees narratives as texts that are thematically organised within smaller plots, with the prerequisite that they consist of prose text (a story) and not simply of any random words. Adding to the predicament of finding general terms with reference to a narrative approach, Riessman (2008) argues that 'a story' is only one genre within the narrative field.

\subsection{Methodologies linked to narrative approaches}

Narrative approaches towards research differ. Narrative as a research method is also not a fixed method. With reference to narrative methodologies, Clandinin (2006) distinguishes between narrative ways of thinking about experience and narrative methodologies, and states that using the same word to think about phenomena and research methodologies complicates the research field even more.

Researchers like Lieblich et al. (1998) also note that they could hardly locate any comprehensive methodologies that systematically map out the available and existing methods within a narrative approach to research. Whilst involved with narrative methodologies, some researchers focus on the structural links that surround narratives to test both the structure and the context of narratives to reveal insight into different aspects; other researchers examine narratives as a complete story, whilst yet others break it down into smaller parts (Bamberg, 2012; Daiute\& Lightfoot, 2004; Nie, 2017; Feldman, Sköldberg, Brown, \& Horner, 2004; Riessman, 2008).

\footnotetext{
${ }^{1}$ Disciplines mentioned were: humanities, medicine, ethnography, psychoanalysis, developmental theoretics, logico-science, sociolinguistics, phenomenology, literature, social sciences, education, anthropology, sociology, psychology, philosophy and neuroscience.
} 


\subsection{Paradigm of hermeneutic interpretivism}

Narrative research can be situated within a philosophical framework of hermeneutic interpretivism. An interpretive paradigm is characterised by a concern for the individual, where a person (the researcher) tries to understand the subjective world as experienced by another person (Cohen, Manion, \& Morrison, 2018). During the course of the study on the musical identities of students, the researcher interpreted narratives describing experiences, lives and meanings that participating music students attributed to their musical identities.

Kinsella (2006) states that non-positivist qualitative research emphasises understanding and interpretation of human behaviour and is informed by hermeneutic thought. Alessandrini (2012) explains that a non-positivist view sees social actions (lives, experiences) not as existing on their own, but as depending on interpretation to establish their meaning. A non-positivist approach to research is also centred on humanistic views of the social sciences. Therefore, human behaviour, narrated and transcribed as data, is interpreted and reflected upon (Alessandrini, 2012).

Stahl (2007) defines hermeneutics as an approach that can be adopted by a researcher whilst trying to find ways to determine the true meaning as it was intended by an author. Kinsella (2006) describes a hermeneutic approach to research as an attitude that seeks understanding by interpreting text or narratives by constantly moving between the whole and parts of the text. This constant movement (hermeneutic circle) implies a process of interpretation in which the researcher moves between smaller and larger units of meaning in order to determine the meaning of both (Gijsbers, 2017). Gijsbers explains that words or sentences do not have meaning if they are not part of a whole; these larger parts only have meaning because they comprise the smaller parts of which they consist.

A philosophical framework of hermeneutic interpretivism also implies an integration of unfamiliar knowledge or content into existing knowledge, context or content. Thus, this paradigm served as a foundation for the researcher to focus on understanding the way in which the individual participants narrated the meanings that they attributed to their musical identities, which emanate from the world in which they find themselves (Cohen et al., 2018). It is with this philosophical framework in mind that the model of Braun and Clarke (2006) was expanded as explained below.

\subsection{Ontology}

The ontological assumptions within hermeneutic interpretivism research entail the nature of reality for all people involved in the specific research (Stahl, 2007). People create meanings of lived experiences out of their social situations and interactions, and use these meanings to interpret their own reality, which can be both culture-bound and context-bound (Cohen et al., 2018). The implications of the ontological assumption for any research are that both participants and researcher will have individual worldviews that comprise their own realities, and this implies that the researcher's interpretation of participants' narratives should be acknowledged by the participants to validate findings.

In the study to define musical identity, the responsibility lay with the researcher to analyse and interpret data according to accepted qualitative academic methods; the study aimed to include the realities of participants; and to describe the meanings that participants attributed to their musical identities in a way that included each participant's individual concept of reality.

\subsection{Epistemology}

Epistemology is the principle of knowledge (how people know what knowledge is), with specific reference to the ways in which we acquire knowledge (Stahl, 2007). 'Hermeneutics' is a universal term for the science of interpretation. It focuses on the meaning of a specific text, but always within a philosophical grounding of interpretation (Mitchell \&Egudo, 2003).

With reference to epistemology, Cohen et al. (2018) suggest that a researcher needs to focus on relationships between all elements of a person's knowledge and lived experiences.Influencing factors were considered when the researcher attempted to describe the phenomenon (human experience) of this qualitative research, namely, the identities of students of Western Art Music. The mentioned research used narrated life stories of participants as data which had to be transcribed and analysed to find relationships between elements within the told stories.

The epistemological assumption fitted the hermeneutic interpretive paradigm of the research, in which musical identities were defined after the concept of the hermeneutic circle ${ }^{2}$ as a means of analysing data was applied. The hermeneutic circle was applied to move inwards and outwards in interpreting the complete narratives of participants and certain detailed parts of the narratives (Gijsbers, 2017).

\footnotetext{
${ }^{2}$ German philosopher Martin Heidegger's hermeneutical circle has to do with the process of interpreting a text; it is thus an interpretive process in itself. 


\subsection{Storytelling}

Academic research distinguishes between more than one narrative genre (Kim, 2016). For this research, the genre of 'life story' or 'life history', also known as 'life narrative', was used (Kim, 2016). In such research, the relationship between the selves of participants and society is explored within a specific contextual dimension; for this research, the relationship between the participant's self and society was explored within the definite context of undergraduate tertiary study of Western Art Music at a South African tertiary institution. Lieblich et al. (1998) state that 'the story is (their italics) one's identity'. Stories express human experience (Polkinghorne, 1988; Cortazzi, 1993). The importance of storytelling within research is accentuated by Lieblich et al. (1998), who state that people reveal themselves to others through the stories they tell. In the researcher's experience, stories narrated in present time are often reproductions of what people have previously said and done; by telling these stories, people defend how they view concepts or what they do in life. In that way, people's past experiences and the knowledge that was available to them at a specific moment in time become their unique story. Identity is, thus, constituted by the stories a person tells about the self.

For full-time music students, a great deal of their life stories centred around practice sessions, tuition, practical music examinations and performances. The personal stories told by the participating music students comprised "the best possible way to self-understanding" (Zahavi, 2007) their musical identities.

Storytelling can additionally be understood on a more intense level, where it can be seen as a way in which a person sees his or her own world in a new way by telling, re-telling and witnessing the numerous stories of own lived experiences (Swart, 2013). During the process of storytelling, one not only talks about experiences but also interprets these experiences. Bruner (2004) maintains that stories about one's personal life are constantly constructed and reconstructed to find meaning in the situations that one encounters. Stories thus also reveal how people view and understand their lives (Josselson, 2011). Zahavi (2007) states: "Who I am is not something given, but something evolving."

With reference to storytelling, Riessman (1993) claims that within a qualitative, narrative research approach, the object of the investigation is the story itself. The story, as narrative, thus becomes a means of understanding experience (Clandinin\& Connelly, 2000) and claiming identities (Riessman, 1993). The storytellers provide both context and interpretation (Cortazzi, 1993), and narrative research consequently focuses on both these aspects. Riessman (1993) further states that in research on stories, researchers cannot give voice to a participant, but can only record and interpret a story.

In more recent discussions of storytelling, Frank (2010) displays further personal purposes of storytelling and claims that stories help people to orientate themselves within their context in the world; the interpretation of these stories will reveal various ways of understanding the storytellers' world; stories help people to understand themselves; stories help people to develop affiliation with other people; the value of stories lies in the moral pursuit and edification of the storyteller, as well as the listener and reader; and that the interpretations of stories will open new perspectives to the storyteller, listener and reader.

Researchers such as Nasheeda, Abdullah, Krauss, and Ahmed (2019) state that through the process of storytelling, an individual engages in the thinking and talking about their own identity; a person positions himself or herself in society, and describes own beliefs, choices and actions.

\subsection{Advantages of identity research conducted using a narrative approach}

Having adopted a narrative approach towards researching musical identity the researcher refers to Eyre (2007) who is of the opinion that music and narrative share similar goals, namely the expression of thoughts, feelings, emotions and meanings. Eyre (2007) concludes that music and narrative have communal origins in human expression and communication.

When life stories are told, spontaneous emotions are expressed as the narrative unfolds, and these expressions enable the experience of storytelling to be fully understood and accepted as part of a person's life story (Greenberg \& Angus, 2004). Thus, the musical identities of the students (the phenomenon being studied) could be extracted from their narratives as they told their individual stories about their musical lives.

Through stories, "researchers gain insight into the way human beings understand and enact their lives" (Sandelowski, 1991). The music students participating in this study revealed some of the factors that influenced their identities, such as interaction with other people; relationship with lecturer or music teacher that gives practical tuition on the instrument or voice; the perceptions of society towards musicians and students of Western art Music; self-esteem; practising; and 
performing. These musical identities were interpreted using a specific methodology, which was situated within the philosophical framework of hermeneutic interpretivism.

\subsection{Methodology}

Lieblich et al. (1998) point out that there is almost no comprehensive model that maps out the methods of analysing narratives as data. However, an analysis of narratives does have an interpretive thrust (Lieblich et al., 1998; Mitchell \&Egudo, 2003), which was deemed appropriate for thisparticular study on musical identity.

When narratives are analysed, a researcher needs to decide whether the focus of data analysis will be primarily on what was told; how it was told; for what purpose it was told or to whom it was told (Riessman, 2008). Lieblich et al. (1998) contribute to the debate on the methodology of analysis by outlining four models of classification, which offer different ways of analysing narratives, with each emphasising primarily either the content or the structure. Within Lieblich et al.'s (1998) four models, Riessman (2008) refined four methods for analysing narratives: thematic analysis, which focuses on what was said; structural analysis, which focuses on the linguistic and sequential composition of the story; dialogical/performance analysis, which emphasises contexts, and analysis of visual genres, such as paintings and photography.

When analysing data, the researcher also needs to make another important decision, and that is whether the analysis will be driven by the research questions, a pre-existing coding frame, the previewed literature, or by the data alone (Braun \& Clarke, 2006). However, the paradigm, research approach and methodology of any research study should ideally be aligned with all such possibilities, as well as with the research questions. Furthermore, it is imperative for a researcher to explain reasons for having chosen choosing a specific methodological approach (Braun \& Clarke, 2006).

\subsection{Braun and Clarke's (2006) model for thematic analysis applied and expanded}

Terms, suggested by Braun and Clarke (2006) to use during analysis are: 'data corpus', referring to all data; 'data set', referring to a specific part of the data corpus that is analysed; 'data item', referring to a single interview with one of the participants; and 'data extract', referring to a smaller part of a data item that has been identified and coded by the researcher.

A philosophical framework of hermeneutic interpretivism enabled the researcher to focus on the content of the stories of the music students who participated in the research. This method involved adopting the approach of hermeneutic thought to interpret the meanings that these students attributed to their musical identities. This way of conducting the study was also in line with the ontological and epistemological assumptions of the research because it allowed the reality of being a music student to be exposed and analysed. For this study each data set was analysed with the context of the entire story in mind. This way of analysing data is described by Lieblich et al. (1998) as the "holistic-content mode of reading'. This holistic approach is elucidated by Badenhorst (2015), who explains that stories also tell us something useful about society, because stories are social products, not necessarily facts.

To maintain high ethical standards in which peoples' narrated stories are treated, data triangulation was applied during phases one and four using Braun and Clarke's (2006) six-phase method, because it enabled the researcher to interpret various data items in a holistic way from multifaceted points of view.

The advice given by Gibbs (2015) on practical ways in which data could be analysed proved extremely useful. Gibbs recommends that when looking for codes, a researcher should also look out for: denotations of time and place; the speaker's way of referring to past, present and future; different ways in which a narrator refers to himself or herself, and repetitions of specific themes. The researcher was thus not convinced that using only Braun and Clarke's (2006) model for thematic analysis would suffice to explore all meanings that the music students gave to their musical identities; data triangulation was therefore applied.

\subsubsection{Analysis of data during this research}

Nieuwenhuis (2007) states that in qualitative research the process of analysing data is an ongoing and non-linear one and is not simply a number of consecutive steps. Feldman et al. (2004) furthermore, assume that with interpretive analysis there is more than one way to see a story. The researcher chose a well-developed research method to analyse the data, namely the step-by-step thematic analysis method suggested by Braun and Clarke (2006). This method which entails a complex and comprehensive analysis of datawas further expanded by the researcher.

\subsubsection{Phase one: Familiarising myself with the data}

The transcription of the stories was done as a first step to familiarise the researcher with the data. All names of teachers, colleagues and friends that were mentioned by the participating music students were removed to assure anonymity and all ten participants' stories were re-read to pinpoint the overall impression of each story. These transcriptions were then sent to the participants via email for verification. 
A broad theme was applied to each story to enable the researcher to interpret the data from a certain perspective. Gibbs (2018) mentions that life stories usually have a larger theme, and he suggests the following themes:

- the relational story (when there are constant referrals to other people);

- belonging and separateness (identity with referral to relationships);

- closeness, remoteness and experience of moving (changes in life);

- the idea of career (occupational role describes an identity, e.g. I am a nurse/soldier/teacher. Work becomes a calling.);

- intimate relations (intimate sexual relationships);

- a focus on early life as a determinant of later actions (referring to earlier life to explain current life).

These themes as suggested by Gibbs (2018) were assigned to each story as a first manner to apply the hermeneutical approach of the research.

\subsubsection{Phase two: Generating initial codes}

Open coding, as described by Cohen et al. (2018) was done during this phase. Open coding is a process where a label is attached to a data item that describes or categorises the item. Data items comprised of lines, phrases or paragraphs that appeared relevant to the identity of the participants. According to Braun and Clarke (2006), this phase is driven by data and there are no pre-set codes. They suggest that a researcher codes as many potential themes as possible. The verbatim transcriptions of the conversations between the researcher and participants of this research were printed out on A4 pages in landscape format with a large margin on the right-hand side, to allow space for written codes.

Some lines, sentences, phrases or paragraphs allotted more than one code. The guidelines of Clandinin and Connelly (2000) were followed, and the researcher examined the interactions between personal and social experiences to find continuity between past and present experiences and future expectations. These were related to the social context of the participants as full-time students of Western Art Music at a South African tertiary institution. The researcher also attempted to identify the inner experiences of the participants and to explore such experiences in their existential worlds.

\subsubsection{Phase three: Searching for themes}

During this phase of data analysis, both analytical and axial coding, as described by Cohen et al. (2018) were used. Analytical coding is an interpretive coding process; axial coding entails labelling codes into groups that are similar in meaning as regards the phenomenon. During this phase of the study, the codes were re-visited and compared to the individual data items; in doing this, the hermeneutical circle was actively applied. According to Braun and Clarke (2006), researchers should analyse the codes themselves because this process adds to the interpretive nature of the analysis. By the end of this phase it was possible to have some sense of the significance of some themes in relation to the research questions (Braun \& Clarke, 2006).

\subsubsection{Phase four: Reviewing themes}

During this phase, which is the essence of a paradigm of hermeneutic interpretivism, concern for the individual was shown when the researcher tried to evaluate and understand the experiences of each music student. This researcher paid attention to several suggestions by established researchers. These are as follows:

\subsection{Maguire and Delahunt}

Maguire and Delahunt (2017) suggest that the researcher should consider aspects like the following during this phase: whether the themes make sense in terms of a particular study (in this case with reference to musical identity); whether the themes are supported by the data corpus; whether themes overlap; whether themes need to be separated; and whether new themes are needed to shed light on the phenomenon.

\subsection{John Dewey's model described by Clandinin and Connelly}

This inductive process is also described by Clandinin and Connelly (2000), who refer to John Dewey's model of threedimensional space for thinking about ways to analyse experience. The researcher was guided by the following notions proposed by Dewey (Clandinin\& Connelly, 2000): find interaction between personal and social experience; find continuity between past, present and future experiences; and relate the experience to a situation or place or social context.

\subsection{Clandinin and Connelly}

The analysis of data with reference to what was experienced in the real world included three further focal points that were used to reduce the stories to a set of understandings. Clandinin and Connelly (2000) mention: turning inward 
(inner experiences such as feelings, doubts and hope); turning outward (experiences in the existential world, such as the environment); and turning backward and forward (how stories move between the past, present and future).

\subsection{Josselson}

In addition to this approach, Josselson (2011) outlines three guidelines to use during such an analysis, namely overall reading and re-reading of the data corpus to develop meaning; identifying the different voices of the individual (voices of conflict within a person); and continuing sensitivity by the researcher to the different nuances of meanings that may be expressed.

\subsection{Triangulation: Nie, Sargeant and May}

Analysis triangulation is described by Nie (2017) as a combination of two or more methodological approaches within the same study. Sargeant (2012) adds that triangulation is done to yield an additional comprehensive view of the phenomenon being studied. May (2012) also advocates data triangulation, and suggests the following procedure: start data analysis with thematic analysis, coding and finding themes; focus on the coherence of the story and phenomenon; focus on themes and look for new themes and develop a second generation of themes by looking at the data in another way than thematic analysis (she suggests looking at the construction of the narratives).

\subsection{Gibbs}

Gibbs (2018) outlines new possibilities when he mentions that a researcher can also look for events, experiences, accounts, and excuses within data items. Gibbs also suggests that individual stories could each be dramaturgically classified as either:

- romance (the hero of a story faces certain challenges on the way to a goal and to overcome the obstacles);

- comedy (the goal is to restore social order and the hero of the story has special social skills to overcome the threats to the social order);

- tragedy (the hero of a story is defeated by certain forces and is disliked by society);

- satire (cynical or sceptical viewpoint on social hegemony).

\subsection{Labov}

During this phase of reviewing the themes, the researcher applied yet another way to extricate themes. Labov's (2013) model of interpretation divides data extracts into six elements, with the purpose of focusing on the structure of stories to identify meaning that is given by the storyteller (Gibbs, 2008; Labov, 2013; Riessman, 2008). Certain data extracts were fitted into six elements (abstract, orientation, complicating action, resolution, evaluation, and coda) and the outcomes were interpreted to uncover possible new themes and to examine meanings that the participating music students attributed to their individual musical identities.

\subsection{Wylie, White, Freedman and Combs, Carr and Morgan}

Life stories were also examined to identify the following elements:

- The dominant story. Wylie (1994) mentions that in every culture, people give a particular meaning to their own stories by organising particular events according to a timeline. This becomes one's own personal history and life story (White, 2007).

- Additional stories. A dominant story may contain other stories. Freedman and Combs (2002) suggest that questions are asked to explore the history of these additional stories. The answers to these questions will almost always lead to a description of the constraining narratives and beliefs that underpin the dominant story (Carr, 2005). However, specific questions cannot be written down prior to a conversation because the researcher will not be able to predict the flow of the conversation - hence the need for audio recordings (which were made during this particular research) .

- Supportive members. Conversations and the exploration thereof acknowledge the respected and valuable contributions that other people have made to the lived experiences of the participant (Morgan, 2000).

\subsection{Reviewing themes: conclusion}

Josselson's (2011) view is that findings in narrative research will always be intertwined and interconnected because people's lived experiences are complex, connected and have blurred boundaries. The hermeneutic interpretivist paradigm proved relevant to reveal as many meanings as possible that the participating music students attributed to their individual identities.

\subsubsection{Phase five: Defining and naming themes}

The aim of this phase was to identify the core aspects of musical identity by identifying which parts of the data corpus were relevant to the phenomenon (Braun \& Clarke, 2006). Interpreted findings were displayed in a separate chapter and 178 
incorporated in another chapter of the study where the narrative core of the research was presented. Findings were also merged into information of the chapter answering the research questions.

\subsubsection{Phase six: Writing down and producing the report}

This phase of the study entailed the presentation of the narrative core and addressing the research questions.

\subsection{Conclusion}

Kumar (2014) is of the opinion that the narrative technique of gathering information does not have any predetermined content except for the notion that the researcher seeks to hear a personal story. 'Data' in the analysis of narratives of this particular study comprised words that described the participants' actions, knowledge, decisions, views, beliefs, perceptions, values and feelings within their social environments. The data, after interpretation, offered clear views of the identities that the participants ascribed to themselves.

The detailed process of analysing data adopted during this study supported the credibility of the qualitative nature of this research. Kumar (2014) and Schurink, Fouché and De Vos (2011) concur that for research to be credible a researcher should take the findings back to participants (which was done) to obtain confirmation and approval (credibility), and the process of analysis needs to be described in an extensive and thorough manner (transferability).

Riessman (1993) states that narrative analysis "allows for systematic study of personal experience and meaning." A paradigm of hermeneutic interpretivism can thus be seen as a way to conduct narrative analysis with, because the systematically application of different angles to interpret data was proved useful.

\section{Reference List}

Alessandrini, M. (2012). Non-positivist approaches to research in the Third Sector: Empowered policy-making. Conference Working Papers Series Volume VIII, 1-17. [Refereed Conference Paper]

Badenhorst, C. (2015, July 3). Writing the methodology chapter in a dissertation [Video file]. Retrieved from https://youtu.be/I6ZoCuzixao

Bamberg, M. (2012). Narrative analysis. In H. Cooper, P. M. Camic, D. L. Long, A. T. Panter, D. Rindskopf, \& K. J. Sher (Eds.), APA handbook of research methods in psychology, Vol 2: Research designs: Quantitative, qualitative, neuropsychological, and biological. (Vol. 2). Washington: American Psychological Association. Retrieved March 2, 2019, from www2.clarku.edu/ mbamberg/...files/narrative\%20analysis.doc

Braun, V., \& Clarke, V. (2006). Using thematic analysis in psychology. Qualitative Research in Psychology, 3(2), 77101. doi:10.1191/1478088706qp063oa

Bruner, J. (2004). The narrative creation of self. In L. E. Angus, \& J. McLeod (Eds.), The handbook of narrative psychotherapy: Practice, theory and research (pp. 3-14). Thousand Oaks: Sage Publications

Carr, A. (2005). Narratives of hope. In A. Vetere, \& E. Dowling (Eds.), Narrative Therapies with Children and Their Families: A Practitioner's Guide to Concepts and Approaches (pp. 268-282). London: Routledge. doi:https://doi.org/10.4324/9781315687063

Clandinin, D. J. (2006). Narrative Inquiry: A Methodology for Studying Lived Experience. Research Studies in Music Education, 27(1), 44-54. doi:https://doi.org/10.1177/1321103X060270010301

Clandinin, D. J. (2007). PART I - Situating Narrative Inquiry. In D. J. Clandinin (Ed.), Handbook of narrative inquiry: Mapping a methodology (pp. i-xv). Thousand Oaks: Sage Publications.

Clandinin, D. J., \& Connelly, F. M. (2000). Narrative inquiry: experience and story in qualitative research. San Francisco: Jossey-Bass.

Cohen, L., Manion, L., \& Morrison, K. (2018). Research methods in education ( $8^{\text {th }}$ ed.). New York: Routledge.

Cortazzi, M. (1993). Narrative analysis. London: The Falmer Press.

Creswell, J. W. (2013). Qualitative inquiry and research design: choosing among five approaches ( ${ }^{\text {rd }}$ ed.). Thousand Oaks: Sage Publications.

Daiute, C., \& Lightfoot, C. (2004). Introduction. In C. Daiute, \& C. Lightfoot (Eds.), Narrative analysis: Studying the development of individuals in society (pp. $\mathrm{x}$-xi). Thousand Oaks: Sage Publications.

De Fina, A. (2003). Studies in narrative: A study of immigrant discourse. Amsterdam: John Benjamins Publishing Co.

Dys, S. P., Schellenberg, G., \& McLean, K. C. (2017). Musical identities, music preferences and individual differences. In R. MacDonald, D. J. Hargreaves, \& D. Miell (Eds.), Handbook of musical identities (pp. 247-266). New York: Oxford University Press.

Elliott, A. (2001). Concepts of self. Cambridge: Polity Press.

Ely, M. (2007). In-forming re-presentations. In D. J. Clandinin (Ed.), Handbook of narrative inquiry: Mapping a methodology (pp. 567-598). Thousand Oaks: Sage Publications. 
Evans, P., \& McPherson, G. E. (2015). Identity and practice: The motivational benefits of a long-term musical identity. Psychology of Music, 43(3), 407-422. doi:https://doi.org/10.1177/0305735613514471

Eyre, L. (2007). The Marriage of Music and Narrative: Explorations in Art, Therapy, and Research. Voices: A world forum for music therapy, 7(3). doi:https://doi.org/10.15845/voices.v7i3.54

Feldman, M. S., Sköldberg, K., Brown, R. N., \& Horner, D. (2004). Making Sense of Stories: A Rhetorical Approach to Narrative Analysis. Journal of Public Administration Research and Theory, 14(2), 147-170. doi:https://doi.org/10.1093/jopart/muh010

Frank, A. W. (2010). Letting stories breathe: A Socio-narratology. Chicago: The University of Chicago Press

Freedman, J., \& Combs, G. (2002). Narrative Therapy with couples...and a whole lot more!: A collection of papers, essays and exercises. Adelaide: Dulwich Centre Publications.

Gallagher, S. (2007). Pathologies in narrative structures. In D. D. Hutto (Ed.), Narrative and understanding persons (pp. 203-224). Cambridge: Cambridge University Press

Gibbs, G. R. (2015, February 21). The analysis of narratives [Video File]. Retrieved from https://youtu.be/ZJbnPKJmrpY

Gibbs, G. R. (2018). Analyzing qualitative data ( $2^{\text {nd }}$ ed.). (U. Flick, Ed.) Thousand Oaks: Sage Publications.

Gijsbers, V. (2017, September 27). Chapter 4.1: The hermeneutic circle [Video file]. Retrieved from https://www.youtube.com/watch?v=zIEzc_BBxs

Green, L. (2011). The Globalization and Localization of Learning, Teaching, and Musical Identity. In L. Green (Ed.), Learning, Teaching, and Musical Identity (pp. 1-19). Bloomington: Indiana University Press.

Greenberg, L. S., \& Angus, L. E. (2004). The contributions of emotion processes to narrative change in psychotherapy: A dialectical constructivist approach. In L. E. Angus, \& J. McLeod (Eds.), The Handbook of Narrative and Psychotherapy (pp. 331-349). Thousand Oaks: Sage Publications.

Gruhn, W., Täht, K., Kiilu, K., Ristmägi, R., \&Pöder, K. (2017). Musical identity formation. The Finnish Journal of Music Education, 20(2), 8-21.

Hargreaves, D. J., Miell, D., \& MacDonald, R. A. R. (2002). What are musical identities, and why are they important? In R. A. R. MacDonald, D. J. Hargreaves, \& D. Miell (Eds.), Musical Identities (pp. 1-20). Oxford: Oxford University Press.

Hatch, J. A., \& Wisniewski, R. (1995). Life history and narrative: questions, issues, and exemplary works. In J. A. Hatch, \& R. Wisniewski (Eds.), Life history and narrative (pp. 113-135). London: The Falmer Press.

Horowitz, M. J. (2012). Self-identity theory and research methods. Journal of Research

Practice, 8(2), Article M14. Retrieved from http://jrp.icaap.org/index.php/jrp/article/view/296/261

Josselson, R. (2011). Narrative research: Constructing, deconstructing and reconstructing story. In F. J. Wertz, K. Charmaz, L. M. McMullen, R. Josselson, R. Anderson, \& E. McSpadden (Eds.), Five ways of doing qualitative analysis: Phenomenological psychology, grounded theory, discourse analysis, narrative research, and intuitive inquiry (pp. 224-242). New York: The Guilford Press.

Kim, J. (2016). Understanding narrative inquiry: the crafting and analysis of stories as research. Thousand Oaks: Sage Publications.

Kinsella, E. A. (2006). Hermeneutics and critical hermeneutics: exploring possibilities within the art of interpretation. Forum: Qualitative Social Research, 7(3). doi:10.17169/fqs-7.3.145

Kumar, R. (2014). Research methodology $\left(4^{\text {th }}\right.$ ed.). Thousand Oaks: Sage Publications.

Labov, W. (2013). The language of life and death: The transformation of experience in oral narrative. New York: Cambridge University Press.

Lieblich, A., Tuval-Mashiach, R., \&Zilber, T. (1998). Narrative research: Reading, analysis and interpretation. Thousand Oaks: Sage Publications.

Maguire, M., \& Delahunt, B. (2017). Doing a thematic analysis: A practical, step-by-step guide for learning and teaching scholars. All Ireland Journal of Teaching and Learning in Higher Education, 9(3). Retrieved from http://ojs.aishe.org/index.php/aishe-j/article/view/335/553

May, V. (2012, May 6). What is narrative analysis? [Video file]. Retrieved from https://youtube.be/A7TfEVHHZzl

Mitchell, M. \&Egudo, M. (2003). A review of narrative methodology. Australian Government Department of Defence, Defence Science and Technology Organisation. Land Operations Division. Systems Sciences Laboratory. DSTO-

GD-0385.Retrieved

from https://www.webpages.uidaho.edu/css506/506\%20readings/review\%20of\%20narritive\%20methodology\%20a ustralian\%20gov.pdf

Morgan, A. (2000). What is narrative therapy? An easy-to-read introduction. Adelaide: Dulwich Centre Publications. 
Nasheeda, A., Abdullah, H. B., Krauss, S. E., \& Ahmed, N. B. (2019). Transforming transcripts into stories: a multimethod approach to narrative analysis.

International Journal of Qualitative Methods. https://doi.org/10.1177/1609406919856797

Nie, Y. (2017). Combining Narrative Analysis, Grounded Theory and Qualitative Data Analysis Software to Develop a Case Study Research. Journal of Management Research, 9(2). doi:https://doi.org/10.5296/jmr.v9i2.ten841

Nieuwenhuis, J. (2007). Analysing qualitative data. In K. Maree (Ed.), First steps in research (pp. 98-122). Pretoria: Van Schaik.

Pöder, K., \&Kiilu, K. (2015). The formation of musical identity. The European Journal of Social \& Behavioural Sciences EJSBS, XII(153), 1704-1711. doi:http://dx.doi.org/10.15405/ejsbs.153

Polkinghorne, D. E. (1988). Narrative knowing and the human sciences. Albany: State University of New York Press.

Polkinghorne, D. E. (1995). Narrative configuration in qualitative analysis. In J. A. Hatch, \& R. Wisniewski (Eds.), Life history and narrative (pp. 5-23). London: The Falmer Press.

Riessman, C. K. (1993). Narrative analysis. Thousand Oaks: Sage Publications.

Riessman, C. K. (2008). Narrative methods for the human sciences. Thousand Oaks: Sage Publications.

Riessman, C. K., \& Speedy, J. (2007). Narrative inquiry in the psychotherapy professions: A critical review. In D. J. Clandinin (Ed.), Handbook of narrative inquiry: Mapping a methodology (pp. 426-456). Thousand Oaks: Sage Publications.

Robert, D., \&Shenhav, S. (2014). Fundamental Assumptions in Narrative Analysis: Mapping the Field. The Qualitative Report, 19(38), 1-17. Retrieved from https://nsuworks.nova.edu/tqr/vol19/iss38/3/

Sandelowski, M. (1991). Telling Stories: Narrative Approaches in Qualitative Research. Journal of Nursing Scholarship, 23(3), 161-166. doi: https://doi.org/10.1111/j.1547-5069.1991.tb00662.x

Sargeant, J. (2012). Qualitative Research Part II: Participants, Analysis, and Quality Assurance. Journal of Graduate Medical Education, 4(1), 1-3. doi:https://doi.org/10.4300/JGME-D-11-00307.1

Schurink, W., Fouché, C. B., \& de Vos, A. S. (2011). Qualitative data analysis and interpretation. In A. S. de Vos, H. Strydom, C. B. Fouché, \& C. S. L. Delport (Eds.), Research at grass roots: For the social sciences and human services professions. (4 ${ }^{\text {th }}$ ed., pp. 367-423). Pretoria: Van Schaik.

Spychiger, M. B. (2017). From musical experience to musical identity: Musical self- concept as a mediating psychological structure. In R. MacDonald, D. J. Hargreaves, \& D. Miell (Eds.), Handbook of musical identities (pp. 267-287). New York: Oxford University Press.

Stahl, B. C. (2007). Positivism or non-positivism - Tertium non datur. In R. Sharman, R. Kishore, \& R. Ramesh (Eds.), Ontologies. A handbook of principles, concepts and applications in information systems (pp. 115-142). Boston: Springer. doi:https://doi.org/10.1007/978-0-387-37022-4_5

Swart, C. (2013). Re-authoring the world: The narrative lens and practices for organisations, communities and individuals. Randburg: Knowles Publishing.

Talbot, B. C. (2013). The Music Identity Project. Action, Criticism, and Theory for Music Education, 12(2), 60-74. Retrieved from https://cupola.gettysburg.edu/cgi/viewcontent.cgi?article=1005\&context=consfacpub

Walshaw, M. (2008). The concept of identity positioning the self within research.

Retrieved from : https://www.mathunion.org/fileadmin/ICMI/files/About_ICMI/ Publications_about_ICMI/ICME_11/ Walshaw.pdf

White, M. (2007). MAPS of Narrative Practice. New York: Norton.

Wylie, M. S. (1994). Panning for gold. The Family Therapy Networker, 40-48. Retrieved from https://www.scribd.com/document/220599242/PANNING-FOR-GOLD

Zahavi, D. (2007). Self and other: The limits of narrative understanding. In D. D. Hutto (Ed.), Narrative and understanding (pp. 179-201). Cambridge: Cambridge University Press. 